\title{
The main sceneries of Chagas disease transmission. The vectors, blood and oral transmissions - A comprehensive review
}

\author{
José Rodrigues Coura/ ${ }^{+}$ \\ Laboratório de Doenças Parasitárias, Instituto Oswaldo Cruz-Fiocruz, Rio de Janeiro, RJ, Brasil
}

\begin{abstract}
This review deals with transmission of Trypanosoma cruzi by the most important domestic vectors, blood transfusion and oral intake. Among the vectors, Triatoma infestans, Panstrongylus megistus, Rhodnius prolixus, Triatoma dimidiata, Triatoma brasiliensis, Triatoma pseudomaculata, Triatoma sordida, Triatoma maculata, Panstrongylus geniculatus, Rhodnius ecuadoriensis and Rhodnius pallescens can be highlighted. Transmission of Chagas infection, which has been brought under control in some countries in South and Central America, remains a great challenge, particularly considering that many endemic countries do not have control over blood donors. Even more concerning is the case of non-endemic countries that receive thousands of migrants from endemic areas that carry Chagas disease, such as the United States of America, in North America, Spain, in Europe, Japan, in Asia, and Australia, in Oceania. In the Brazilian Amazon Region, since Shaw et al. (1969) described the first acute cases of the disease caused by oral transmission, hundreds of acute cases of the disease due to oral transmission have been described in that region, which is today considered to be endemic for oral transmission. Several other outbreaks of acute Chagas disease by oral transmission have been described in different states of Brazil and in other South American countries.
\end{abstract}

Key words: Chagas disease - T. cruzi - vector, blood and oral transmission

The mechanisms for Chagas infection transmission to humans can be divided into primary or main and secondary. Among the main mechanisms are vector, blood transfusion, oral, placental or congenital transmission and through the birth canal at the time of birth. Secondary mechanisms are considered to be less frequent, such as laboratory accidents, handling of infected animals, ingestion of uncooked meat from infected animals, organ transplants from donors infected with Trypanosoma cruzi, sexual transmission and, exceptionally, through induced or criminal infection (Coura 2007). Another possibility is direct transmission from the reservoir of T. cruzi, especially involving marsupials, which eliminate $T$. cruzi through odoriferous glands and can directly transmit the parasite to other animals and to humans (Deane et al. 1984, Lenzi et al. 1984).

Chagas disease was initially an enzooty maintained among wild animals and vectors, which was transmitted accidently to humans, when they invaded the wild ecotope or when wild animals and vectors invaded human homes and this still occurs from the southern United States of America (USA) to southern Argentina and Chile $\left(42^{\circ} \mathrm{N} 49^{\circ} \mathrm{S}\right)$. Over time, with deforestation to make space for agriculture and livestock rearing, triatomines adapted to human peridomestic areas, forming endemic areas in South and Central America and in Mexico. More recently, starting in the 1980 s, attention became drawn to

doi: $10.1590 / 0074-0276140362$

Financial support: FIOCRUZ, CNPq

+ Corresponding author: coura@ioc.fiocruz.br

Received 3 October 2014

Accepted 29 October 2014 the globalisation of Chagas disease through migration of patients to the USA, Europe, Asia and Oceania (Schmunis 2007, Coura \& Dias 2009, Coura \& Viñas 2010).

In nature, there are more than 100 mammal species that are reservoirs for $T$. cruzi, such as marsupials, bats, rodents, carnivores, Xenarthra (armadillos), lagomorphs (rabbits and hares) and primates. On the other hand, more than 140 species of triatomines, belonging to 19 genera and five tribes, are recognised (Galvão et al. 2003), among which the main vectors for T. cruzi are in the genera Panstrongylus, Rhodnius and Triatoma. Although triatomines have been known since the XVI century, they were only identified by De Geer in 1773 (Lent \& Wigodzinsky 1979). However, infection by $T$. cruzi in triatomines, domestic and wild animals and humans was only demonstrated by Carlos Chagas in 1909 during the discovery of the disease that bears his name (Chagas 1909, 1912).

The natural history of the transmission of Chagas infection can be summarised as the following forms: (i) enzooty - infection or disease that is transmitted among wild animals; (ii) anthropozoonosis - infection or disease that is transmitted from animals to humans, either when they invade the wild ecotope or when vectors or wild animals invade human domestic areas; (iii) zoonosis or amphixenosis - infection or disease interchanged between animals and humans; (iv) zooanthroponosis infection or disease that is transmitted from humans to animals, particularly by vectors present in homes to domestic animals (Coura 2013).

\section{Main mechanisms for Chagas infection transmission}

Vector transmission - The main vector of Chagas infection is Triatoma infestans (Klug 1834) in a large portion of South America, which until recently was distributed from southern Argentina to northeastern Brazil. 
This vector probably originated from Bolivia, where it is found in domestic, peridomestic and wild areas and was transported to Argentina, Chile, Paraguay, Uruguay and Brazil, where it became exclusively domestic. Through the Southern Cone Initiative, it was eliminated from Uruguay in 1997, from Chile in 1999 and from Brazil in 2006, according to the certification of the Pan-American Health Organization (Coura \& Dias 2009). Transmission of $T$. cruzi by $T$. infestans was also interrupted in five provinces in Argentina and in eastern Paraguay (Coura et al. 2009). In Brazil, there are still residual foci in the states of Rio Grande do Sul (RS) and Bahia (BA). In Bolivia, where the species is still widely disseminated, there have been reports of occurrences at altitudes of 3,600 $\mathrm{m}$ and it continues to transmit $T$. cruzi in the Andean valleys of Bolivia and in the Gran Chaco. The high genetic variability of $T$. infestans found on a microgeographical scale among wild vectors in the Andean valleys of Bolivia favours the hypothesis that the Andes were the original centre for dispersion of $T$. infestans, which makes this vector a threat that needs to be monitored (Noireau 2009). The failure to eliminate T. infestans from the Gran Chaco, even in areas that underwent intense effort to control this vector, indicates the need for sustained and continued coordination between governments and agencies, with control programs that adopt new strategies (Gürtler 2009).

Panstrongylus megistus (Burmeister, 1835) can be considered today to be the most important potential vector in Brazil, given its wide geographical distribution throughout the country, its susceptibility to T. cruzi and its versatility as a wild vector with easy domestic adaptation. This species is distributed from the Guianas to Argentina and towards Paraguay and Bolivia (Sherlock 2000). In Brazil, P. megistus is distributed from the South to the Northeast, with greatest concentration in the states of Minas Gerais (MG) and BA, occupying wild, peridomestic and domestic ecotopes, while in the South Panstrongylus is essentially wild. At the time when $T$. infestans was present in domestic environments in 711 municipalities in Brazil, it was frequently observed, for example in MG, that once $T$. infestans had been eliminated from a home using insecticide spraying, the home became colonised shortly afterwards by P. megistus and vice versa. In the wild ecotopes of southeastern and southern Brazil, the natural habitat of P. megistus frequently comprises wild nests of marsupials, as demonstrated in the forest of Santa Teresa, state of Rio de Janeiro (RJ) (Coura 1966, Coura et al. 1966a, b). Fig. 1 shows specimens of Didelphis marsupialis and P. megistus captured in Santa Teresa (Coura 1966). P. megistus is perhaps the triatomine with greatest microgeographical diversity, given that it can occupy wild, peridomestic or domestic ecotopes of a given area. The species is currently most frequently found in the riparian zones of the southern, southeastern and northeastern regions of Brazil.

Rhodnius prolixus (Stål, 1859) is one of the most important vectors for T. cruzi due to its anthropophily, rapid development cycle, great density, intense passive dispersion and high susceptibility to infection and trans-

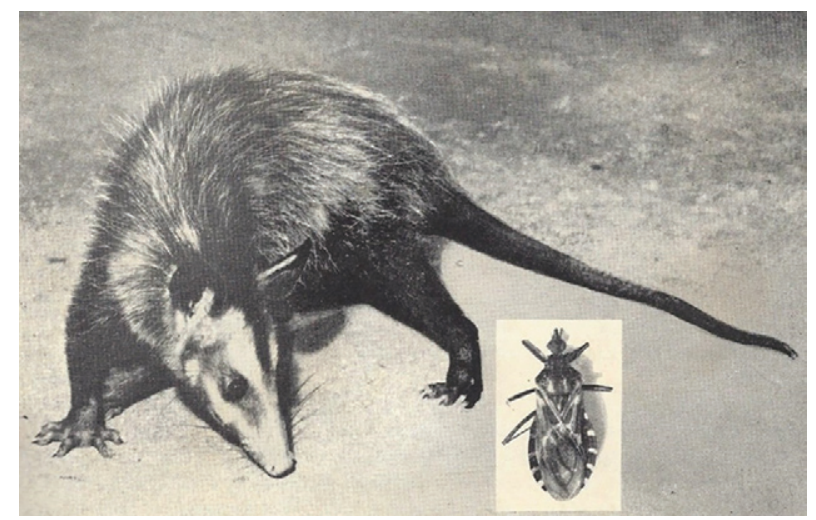

Fig. 1: Didelphis marsupialis and wild Panstrongylus megistus infected with Trypanosoma cruzi captured in Santa Teresa, state of Rio de Janeiro, Brazil (Coura 1966).

mission of T. cruzi. It is the main vector in Colombia, Guyana, French Guyana, Suriname and Venezuela, from where it is believed to have disseminated to Central American countries, with the exception of Panama and Costa Rica. Thus, this vector reaches Andean, Amazon and Central American countries (Guhl 2007). R. prolixus is considered to be a native of Colombia and Venezuela, where it is the main vector for T. cruzi, originally occurring in palm trees, with adaptation to human homes. The dispersion of this species from Venezuela to Central America, where it has been introduced, could have occurred by means of passive carrying of specimens by birds or mammals or in palm tree straws and fibres (Schofield et al. 1999, Guhl 2007). From the information available, El Salvador, Guatemala, Honduras and Nicaragua have eliminated $R$. prolixus with possible isolated foci remaining (Coura et al. 2009).

Triatoma dimidiata (Latreille, 1811) is distributed from Ecuador to Mexico, from the Pacific coastline to the mountain areas, where the species frequents homes, while on the Atlantic side it tends to be wild. In South America, this species can be found in Colombia, Ecuador, Peru and Venezuela and in Central America, in Belize, Costa Rica, El Salvador, Guatemala, Honduras and Nicaragua. It can even be found in Mexico, in North America. In Colombia, this species is found in the central-western region of the country and on the coast of Ecuador and in northern Peru. The wide presence and distribution of T. dimidiata, in addition to its ability to colonise human homes, is one of the reasons why control measures are needed (Ramirez et al. 2005, Guhl 2007, Ponce 2007). T. dimidiata is one of the main vectors in Costa Rica. In other Central American countries where R. prolixus has been eliminated, $T$. dimidiata has become the main target. One peculiarity of this species is that its nymphs camouflage themselves by covering themselves with sand on the ground of homes with dirt floors. Around $50 \%$ of the specimens of $T$. dimidiata that are caught inside homes or in peridomestic areas in Central America present human blood and 25\% have dog blood, thus demonstrating their potential for domestic adaptation. 


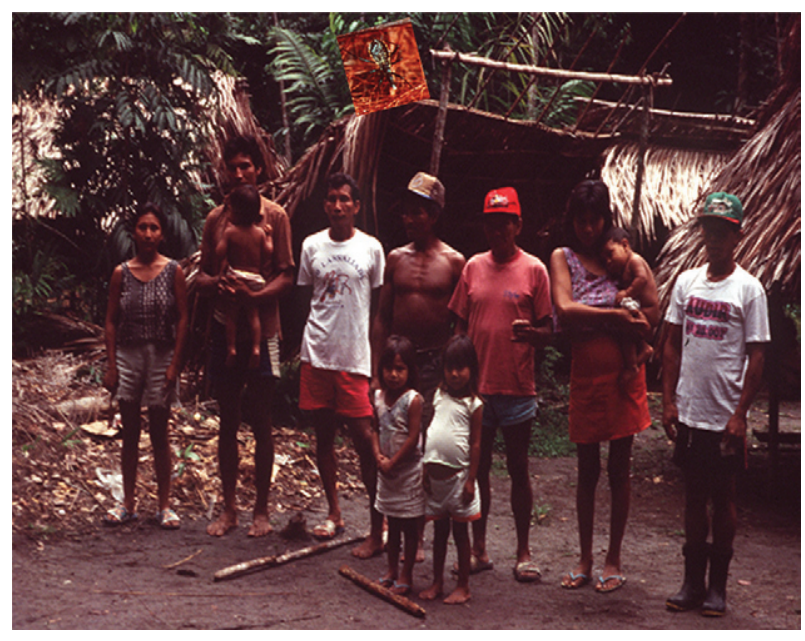

Fig. 2: Rhodnius brethesi in palm tree and piassava's gatherers and their families outside huts in the work place at the microregion of the Rio Negro, Brazilian Amazon.

Triatoma brasiliensis (Neiva, 1911) is the main species in the semi-arid region of northeastern Brazil. Specimens are found in domestic, peridomestic and wild areas, particularly in cracks of rocks in the Caatinga. This species is commonly found in the states of Piauí (PI), Ceará, Rio Grande do Norte, Paraíba (PB), Pernambuco (PE) and northern BA, colonising homes and frequently associated with Triatoma pseudomaculata (Correa \& Spinola, 1964). While T. brasiliensis hosts high levels of infecting T. cruzi and home infestation, T. pseudomaculata eliminates low percentages of infecting metacyclic forms of $T$. cruzi, thus characterising an inefficient vector.

Triatoma sordida (Stål, 1859) seems to have originated from the Brazilian central plateau, from where it disseminated southwards as far as Argentina. Its geographical distribution in Brazil extends from the RS to southwestern PE and southern PI, occupying areas where T. infestans has been eliminated through insecticides. T. sordida is a secondary vector for transmission of T. cruzi. Despite its spatial distribution, most are located in peridomestic areas, especially in chicken coops (Scherlock 2000).

Triatoma maculata (Erickson, 1848) occupies areas in Brazil, the Guianas, Dutch Antilles, Suriname and Venezuela. In Venezuela, after $R$. prolixus, T. maculata is the most important domestic vector, followed by Panstrongylus geniculatus, which was described in Venezuela by Felliciangeli et al. (2004) in the state of Lara, incriminated by the seroprevalence of T. cruzi infection among the human population. In Brazil, T. maculata has been found in chicken coops in peridomestic areas and sporadically within homes in the state of Roraima, in the Brazilian Amazon Region. Thus, this species is a potential vector for T. cruzi (Luitgards-Moura et al. 2005).

P. geniculatus (Latreille 1811) was found by Chagas (1912) in the burrows of the armadillo Dasipus novemcinctus, which were infected with T. cruzi, at the time of the discovery of the wild cycle of Chagas disease. More recently, this species has been found in several wild and peridomestic ecotopes with incursions into human

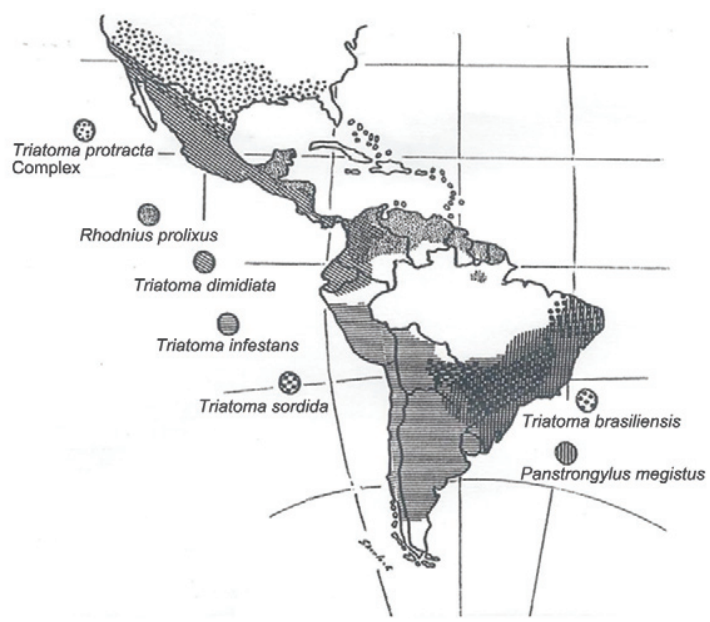

Fig. 3: distribution of the main vectors of Trypanosoma cruzi in the Americas (Scherlock 2000).

homes, thus presenting potential domestic adaptation (Valente et al. 1998, Valente 1999).

Rhodnius ecuadoriensis (Lent \& Leon, 1958) is considered to be an autochthonous vector in western Ecuador, with wild populations and a domestic population that extends from southern Ecuador towards northern Peru, where it has also become established (Guhl 2007). Rhodnius pallescens (Barber, 1932) is the main vector of T. cruzi in Panama and a secondary vector in other countries of Central America and in Colombia (Zeledón et al. 2006, Gómez-Palacio et al. 2008, 2012). Rhodnius brethesi (Matta 1919) is distributed in the Brazilian Amazon, in Colombia and in Venezuela. In Brazil, it is an important wild vector for T. cruzi in the microregion of the Rio Negro, state of Amazonas, especially among piassava fibre gatherers and their families, who remain in the piassava plantations for at least six months a year. In this case, Chagas disease has become an occupational disease for these plant material harvesters (Coura et al. 1994a, b, 1999, 2013, Coura \& Junqueira 2012). Fig. 2 shows $R$. brethesi and piassava's gatherers.

In an excellent review on Chagas disease in Andean countries, Guhl (2007) illustrated the initiatives implemented for controlling Chagas disease in southern cone countries, in Andean countries, in Central America and Mexico and in the Amazon Region. On the other hand, Scherlock (2000) depicted the distribution of the main vectors of T. cruzi in the Americas (Fig. 3).

\section{Transmission by blood transfusion}

Transmission of T. cruzi by means of blood transfusion is still probably the second most frequent transmission mechanism. Until recently, this issue was only evident in Latin America, but with the increase in emigration of Chagas disease patients to non-endemic countries, a new global sceneries for this transmission mechanism has emerged (Coura 1966, Wendel \& Dias 1992, Schmunis 2007, Coura \& Viñas 2010). 


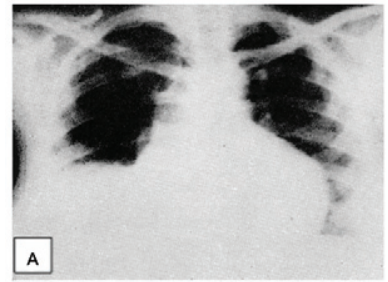

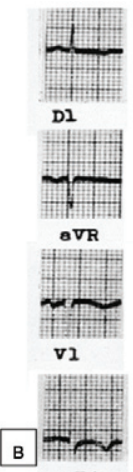

$v_{4}$

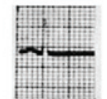

D2

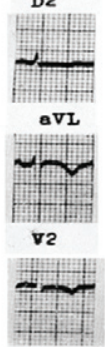

v5

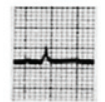

D3
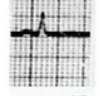

av

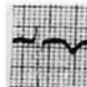

v3

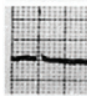

v6
Fig. 4: acute case of Chagas disease acquired by blood transfusion from a chronic case showing $\mathrm{X}$ ray with enlargement and sign of heart failure (A) and electrocardiogram showing myocardial ischaemia (B) (Coura 1966).

Transmission of Chagas disease by blood transfusion was initially suggested by Dias (1945). The first infected donors in Brazil were reported by Pellegrino (1949) and Pellegrino et al. (1951) and the first cases of people who acquired the infection were described by Freitas et al. (1952). Nussenzweig et al. (1953) experimented with chemoprophylaxis by means of gentian violet in blood from donors. It has been estimated that in Brazil alone in the 1970s, there were 100,000 new cases of Chagas disease through blood transfusion every year (Dias \& Schofield 1999). Several serological surveys were carried out in Brazil and in the Americas from 1970 onwards (Wendel \& Dias 1992, Dias \& Schofield 1999). Before this, however, local surveys were carried out (Pellegrino 1949, Pellegrino et al. 1951, Freitas et al. 1952). Coura (1966) conducted serological surveys in two blood banks in RJ, involving 4,595 donors, among whom 58 donors were positive (1.26\%). From these, 24 blood recipients were located. Six, who were autochthonous to RJ, were infected (25\%) and one of these individuals developed an acute form of Chagas disease, with an overall increase in the heart area and signs of acute myocarditis seen on electrocardiogram (Fig.4A, B).

Chagas disease infection due to blood transfusion has decreased, especially through controlling blood donors in the southern cone, particularly in Brazil, Uruguay, Chile and a few other South and Central American countries. However, despite this decrease, the issue remains a great challenge. Many endemic countries have not introduced controls in relation to their blood donors yet and, more worrying still, many non-endemic countries are receiving thousands of migrants from endemic areas who carry Chagas disease. Among these non-endemic countries are the USA, Spain and other countries in Europe, Asia and Oceania (Coura \& Viñas 2010, Coura et al. 2014).

\section{Oral transmission}

Oral transmission of $T$. cruzi is probably the most frequent mechanism among animals in the wild cycle, considering that several species of wild mammals, such as small primates, frequently ingest insects, in this case the triatomines that transmit $T$. cruzi. This was probably first noted at the time of the discovery of Chagas disease
(1909), as mentioned by Carlos Chagas: "Examining the content of the posterior intestines of 'Conorrinus' gathered in Minas Gerais, inside peoples' homes, we observed the presence of numerous flagellates with the characteristics of Crithidia. These haematophagous insects were sent to the Institute and, there, our director, Dr Oswaldo Cruz, tried to infect a Callithrix penicillata monkey, by allowing several specimens of Hemiptera to bite it. Twenty to thirty days later, known species of the genus Trypanosoma were found in the monkey's peripheral blood". Considering that the transmission of T. cruzi through being bitten by a triatomine is very rare, we believe that the monkey had eaten some insects and become infected orally. The first experimental demonstration of oral $T$. cruzi infection was made by Nattan-Larrier (1921), using blood trypomastigotes that were inoculated orally and subsequently using triatomine faeces by Cardoso (1933), Kofoid and Donat (1933) and Marsden (1967). Transmission of Chagas disease through breast milk from mother to children was first described by Mazza et al. (1936).

Chagas disease in the Brazilian Amazon Region has always been considered to be an enzooty transmitted between vectors and wild animals, since the time when Chagas (1924) confirmed T. cruzi as a parasite, isolated from a Saimiri scireus monkey in the state of Pará (PA). Thereafter, it was only 45 years later that Shaw et al. (1969) described the first four acute cases of Chagas disease in Belém, PA, which were probably transmitted orally. Since then, hundreds of acute cases of the disease due to oral transmission have been described in the Amazon Region, which has led to classification of the region as endemic (Valente et al. 1999, 2009). Pinto et al. (2008) alone described 233 acute cases of the disease, most of which were caused by oral transmission in the states of Amapá (AP), Maranhão (MA) and PA. A high proportion of these cases presented the severe acute form of Chagas disease, probably due to a greater inoculation of T. cruzi in oral transmissions (Fig. 5). In 1990, we raised the hypothesis that Chagas disease was endemic to the Brazilian Amazon Region (Coura 1990) and, later on, we carried out a short review of the 38 cases of the disease that had been described up until that time in the states of Acre, PA, AP, AM and MA (Coura et al. 1994b). Oral transmission of Chagas infection within the natural history of the disease was reviewed by Coura (2006).

So far, in AM, there have been three descriptions of outbreaks of acute Chagas disease due to oral transmission, respectively in Tefé, in 2004 (Medeiros et al. 2008),

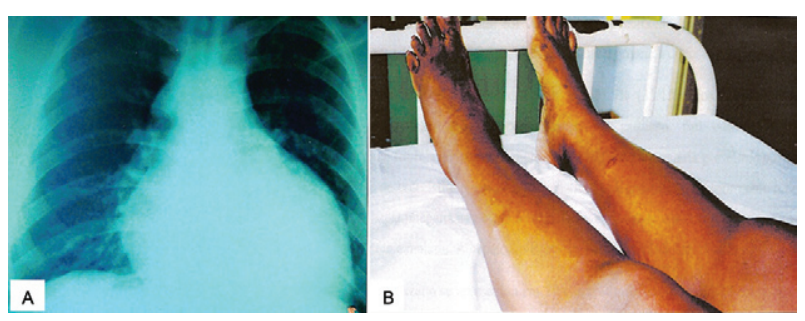

Fig. 5: acute case of Chagas disease by oral transmission showing $\mathrm{X}$ ray heart enlargement (A) and oedema on the legs with skin necrosis (B) (Pinto et al. 2008). 
in Coarí, beside the Solimões River, in 2008 (BarbosaFerreira et al. 2010), and in Santa Izabel do Rio Negro, in 2010 (Souza-Lima et al. 2013).

The first outbreak of probable oral transmission of Chagas infection to humans in Brazil was described in Teutônia (Estrela, RS) by Silva et al. (1968) and NeryGuimarães et al. (1968), without determining the source and this involved 18 people with six deaths. In October 1986, another outbreak of oral transmission occurred in Catolé do Rocha, in PB (Shikanai-Yassuda et al. 1991), involving 26 people with one fatal case, probably transmitted through consumption of sugar cane juice. This was similar to another 19 cases that occurred in Navegantes, state of Santa Catarina, in March 2005, with three deaths.

Several other isolated outbreaks of the disease have been observed in Brazil, with no major repercussion. The greatest outbreak of oral transmission of $T$. cruzi infection, which involved 103 acute cases of Chagas disease, occurred in Caracas, Venezuela, with great international repercussion (de Noya et al. 2010).

Given that more than 100 species of mammals serve as reservoirs for T. cruzi and another 140 species of triatomines serve as potential vectors for the parasite in nature, infection through oral transmission is unavoidable and can be expected to occur throughout Latin America and southern USA. On the other hand, only the epidemic outbreaks of Chagas disease are more evident. Isolated cases are mostly unaccounted for, either because they do not worry the healthcare services or because they are mistaken for other diseases. In this regard, we recommend that integrated actions should be carried out to promote health information and education regarding this form of the disease, in association with training for healthcare professionals, laboratory technicians, doctors, nurses and nursing assistants, with the aim of early diagnosis and treatment of the disease in its initial phase.

\section{REFERENCES}

Barbosa-Ferreira JM, Guerra JAO, Santana FS, Magalhães BML, Coelho LIARC, Barbosa MGV 2010. Acometimento cardíaco em doença de Chagas aguda da Amazônia 2010. Arq Bras Cardiol 94: 147-149.

Cardoso FA 1933. Sur le mécanisme de la transmission de la maladie de Chagas. Ann Parasit Hum Comp 16: 341-349.

Chagas C 1909. Nova tripanozomiaze humana. Estudos sobre a morfolojia e o ciclo evolutivo do Schizotrypanum cruzi n. gen., $n$. sp., ajente etiolojico de nova entidade morbida do homem. Mem Inst Oswaldo Cruz 1: 159-218.

Chagas C 1912. Sobre um Trypanosoma do tatu. Tatusia novemcineta, transmitido pelo Triatoma geniculata Latr (1811). Possibilidade de ser o tatu um depositário do Trypanosoma cruzi no mundo exterior. Nota prévia. Braz Med 26: 305-336.

Chagas C 1924. Infection naturelle dês singes du Pará (Chrysotrix siureus) par Trypanosoma cruzi. Comptes Rendus des Séances de la Societé de Biologie et des Ses Finales 90: 873-876.

Coura JR 1966. Contribuição ao estudo da doença de Chagas no estado da Guanabara. Rev Bras Malariol D Trop 18: 9-98.

Coura JR 1990. The risks of endemic Chagas disease in the Brazilian Amazon. Rev Soc Bras Med Trop 23: 67-70.

Coura JR 2006. Transmissão da infecção chagásica por via oral na história natural da doença de Chagas. Rev Soc Bras Med Trop 39 (Suppl. 4): 113-117.
Coura JR 2007. Chagas disease: what is known and what is needed - A background article. Mem Inst Oswaldo Cruz 102 (Suppl. I): 113-122.

Coura JR 2013. Chagas disease: control, elimination and eradication. Is it possible? Mem Inst Oswaldo Cruz 108: 962-967.

Coura JR, Abad-Franch F, Aguillera X, Dias JCP, Gil H, Junqueira ACV, Lima JF, Moreira JCC, Schall V, Schmunis G 2009. The initiative for the control of Chagas disease in the Americas and in nonendemic countries. Rev Soc Bras Med Trop 42 (Suppl. 2): 106-110.

Coura JR, Barrett TV, Naranjo MA 1994a. Ataque de populações humanas por triatomíneos silvestres no Amazonas: uma nova forma de transmissão da infecção chagásica? Rev Soc Bras Med Trop 27: 251-253.

Coura JR, Dias JCP 2009. Epidemiology, control and surveillance of Chagas disease - 100 years after its discovery. Mem Inst Oswaldo Cruz 104 (Suppl. I): 31-40.

Coura JR, Ferreira LF, Rubens J, Pereira NC, Silva JR 1966a. Tripanosoma do "complexo cruzi" em reservatório silvestre do estado da Guanabara. Estudo de sua patogenicidade. Rev Inst Med Trop Sao Paulo 8: 134-138.

Coura JR, Ferreira LF, Silva JR 1966b. Triatomines no estado da Guanabara e suas relações com o domicílio humano. Rev Inst Med Trop Sao Paulo 8: 162-166.

Coura JR, Junqueira ACV 2012. Risks of endemicity, morbidity and perspectives regarding the control of Chagas disease in the Amazon Region. Mem Inst Oswaldo Cruz 107: 145-154.

Coura JR, Junqueira ACV, Boia MN, Fernandes O 1999. Chagas disease: from bush to huts and houses. Is it the case of the Brazilian Amazon? Mem Inst Oswaldo Cruz 94 (Suppl. I): 379-384.

Coura JR, Junqueira ACV, Giordano CM, Funatsu RK 1994b. Chagas disease in the Brazilian Amazon. I - A short review. Rev Inst Med Trop Sao Paulo 36: 363-368.

Coura JR, Viñas PA 2010. Chagas disease: a new worldwide challenge. Nature 465 (Suppl.): S6-S7.

Coura JR, Viñas PA, Brum-Soares LM, de Sousa AS, Xavier SS 2013. Morbidity of Chagas heart disease in the microregion of Rio Negro, Amazonian Brazil: a case-control study. Mem Inst Oswaldo Cruz 108: 1009-1013.

Coura JR, Viñas PA, Junqueira ACV 2014. Ecoepidemiology, short history and control of Chagas disease in the endemic countries

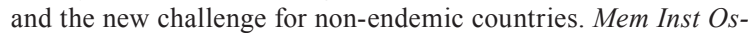
waldo Cruz 109: 856-862.

de Noya BA, Dias-Bello Z, Colmenares C, Ruiz-Guevara R, Mauriello L, Zavala-Jaspe R, Suarez JA, Abate T, Naranjo L, Paiva M, Rivas L, Castro J, Márques J, Mendoza I, Acquatella H, Torres J, Noya O 2010. Large urban outbreak of orally acquired acute Chagas disease at a school in Caracas, Venezuela. J Infect Dis 201: 1308-1315.

Deane MP, Lenzi HL, Jansen A 1984. Trypanosoma cruzi: vertebrate and invertebrate cycles in the same mammal host, the opossum Didelphis marsupialis. Mem Inst Oswaldo Cruz 79: 513-515.

Dias E 1945. Um ensaio de profilaxia da moléstia de Chagas, Imprensa Nacional, Rio de Janeiro, 116 pp.

Dias JCP, Schofield CJ 1999. The evolution of Chagas disease (American trypanosomiasis) control after 90 years since Carlos Chagas discovery. Mem Inst Oswaldo Cruz 94 (Suppl. I): 103-121.

Feliciangeli MD, Carrasco H, Paterson JS, Suarez B, Martinez C, Medina M 2004. Mixed domestic infestation by Rhodnius prolixus (Stål, 1859) and Panstrongylus geniculatus (Latreille, 1881), vector incrimination and seroprevalence for Trypanosoma cruzi among inhabitants in El Guamito, Lara state, Venezuela. Am J Trop Med Hyg 71: 501-505. 
Freitas JLP, Biancalaria A, Amato Neto V, Nussenzweig V, Sonttag R, Barreto JG 1952. Primeiras verificações de transmissão acidental da moléstia de Chagas ao homem por transfusão de sangue. Rev Paul Med 40: 36-40.

Galvão C, Carvalho RU, Rocha DS, Juberg J 2003. A check-list of the current valid species of the subfamily Triatominae Jeannel, 1919 (Hemiptera, Reduviidae) and their geographical distribution, with nomenclatural and taxonomic notes. Zootaxa 2002: 1-36.

Gómez-Palacio A, Jaramillo-Ocampo N, Caro-Riaño H, Diaz S, Monteiro FA, Pérez R, Panzera F, Triana O 2012. Morphometric and molecular evidence of infraespecific biogeographical differentiation of Rhodnius pallescens (Hemiptera: Reduviidae: Rhodniini) from Colombia and Panama. Infect Genet Evol 12: 1975-1983.

Gómez-Palacio A, Jaramillo-Ocampo N, Triana-Chávez O, Saldaña A, Calzada J, Pérez R, Panzera F 2008. Chromosome variability in the Chagas disease vector Rhodnius pallescens (Hemiptera, Reduviidae, Rhodniini). Mem Inst Oswaldo Cruz 103: 160-164.

Guhl F 2007. Chagas disease in Andean countries. Mem Inst Oswaldo Cruz 102 (Suppl. I): 29-37.

Gürtler RE 2009. Sustainability of vector control strategies in the Gran Chaco Region: current challenges and possible approaches. Mem Inst Oswaldo Cruz 104 (Suppl. I): 52-59.

Kofoid CA, Donat F 1933. Experimental infection with Trypanosoma cruzi from intestine of cone-nose bug, Triatoma protracta. Proc Soc Exp Biol Med 30: 489-491.

Lent H, Wygodzinsky P 1979. Revision of Triatominae (Hemiptera, Reduviidae) and their significance as vectors of Chagas disease. Bull Am Mus Nat Hist 63: 125-520.

Lenzi HL, Jansen AM, Deane MP 1984. The recent discovery of what might be a primordial escape mechanism for Trypanosoma cruzi. Mem Inst Oswaldo Cruz 79: 13-18.

Luitgards-Moura JF, Vargas AB, Almeida CE, Magno-Esperança G, Agapito-Souza R, Folly-Ramos E, Costa J, Tsouris P, RosaFreitas MG 2005. A Triatoma maculata (Hemiptera, Reduviidae) population from Roraima, Amazon Region, Brazil, has some bionomic characteristics of potential Chagas disease vector. Rev Inst Med Trop Sao Paulo 47: 131-137.

Marsden PD 1967. Trypanosoma cruzi infection in CFI nice. II - Infection induced by different routes. Ann Trop Med Parasitol 61: 62-67.

Mazza S, Montana A, Benitez C, Janzi Z 1936. Transmission del Schizotrypanum cruzi al niño por leche de la madre con enfermedad de Chagas. Mepra, Mision de Estudios de Patologia Regional Argentina 28: 41-46.

Medeiros MB, Guerra JAO, Lacerda MGV 2008. Meningoencefalite em paciente com doença de Chagas aguda na Amazônia brasileira. Rev Soc Bras Med Trop 41: 220-221.

Nattan-Larrier L 1921. Infectious à trypanosomes et voies de penetration dos vírus. Bull Soc Pathol Exot Filiales 14: 537-542.

Nery-Guimarães F, Silva N, Clausell DT, Mello AL, Rapone T, Snell T, Rodrigues N 1968. Um surto epidêmico de doença de Chagas de provável transmissão digestiva, ocorrido em Teutônia (Estrela, Rio Grande do Sul). Hospital (Rio J) 73: 1767-1804.

Noireau F 2009. Wild Triatoma infestans, a potential threat that needs to be monitored. Mem Inst Oswaldo Cruz 104 (Suppl. I): 60-64.

Nussenzweig V, Sonntag R, Biancalana A, Freitas JLP, Amato Neto V, Kloetzel J 1953. Ação de corantes trifenil-metânicos sobre o Trypanosoma cruzi "in vitro". Emprego da violeta de genciana na profilaxia da transmissão da moléstia de Chagas por transfusão de sangue. Hospital (Rio J) 44: 731-744.

Pellegrino J 1949. Transmissão da doença de Chagas pela transfusão de sangue. Primeiras comprovações sorológicas em doadores e candidatos a doadores de sangue. Rev Bras Med 6: 297-301.
Pellegrino J, Borrtchin M, Leite G, Brener Z 1951. Inquérito sôbre a doença de Chagas em candidatos a doadores de sangue. Mem Inst Oswaldo Cruz 49: 555-564.

Pinto AY, Valente SAS, Valente VC, Ferreira Junior AG, Coura JR 2008. Fase aguda da doença de Chagas na Amazônia brasileira. Estudo de 233 casos do Pará, Amapá e Maranhão, observados entre 1988 e 2005. Rev Soc Bras Med Trop 41: 602-614.

Ponce C 2007. Current situation of Chagas disease in Central America. Mem Inst Oswaldo Cruz 102 (Suppl. I): 41-44.

Ramirez CJ, Jaramillo C, Delgado MP, Pinto N, Aguilera G, Guhl F 2005. Genetic structure of sylvatic peridomestic and domestic population of Triatoma dimidiata (Hemiptera: Reduviidae) from an endemic zone of Boyacá, Colômbia. Acta Trop 93: 24-29.

Schmunis GA 2007. Epidemiology of Chagas disease in non-endemic countries: the role of international migration. Mem Inst Oswaldo Cruz 102 (Suppl. I): 75-85.

Schofield CJ, Diotaiuti L, Dujardin JP 1999. The process of domestication in Triatominae. Mem Inst Oswaldo Cruz 94 (Suppl. I): 375-378.

Shaw J, Lainson R, Fraiha H 1969. Considerações sobre a epidemiologia dos primeiros casos autóctones de doença de Chagas registrados em Belém, Pará, Brasil. Rev Saude Publica 3: 153-157.

Sherlock IA 2000. Vetores. In Z Brener, ZA Andrade, M Barral Netto, Trypanosoma cruzi e doença de Chagas, 2nd ed., Guanabara Koogan, Rio de Janeiro, p. 21-40.

Shikanai-Yassuda MA, Marcondes CA, Guedes LA, Siqueira GS, Barone AA, Dias JCP, Amato Neto V, Tolezano JE, Peres HA, Arruda Jr ER, Lopes MH, Shiroma M, Chapadeiro E 1991. Possible oral transmission of acute Chagas disease in Brazil. Rev Inst Med Trop Sao Paulo 33: 351-357.

Silva NN, Clausell DT, Núbilos II, Mello AL, Ossanai J, Rapone T, Snell T 1968. Surto epidêmico de doença de Chagas com provável contaminação oral. Rev Inst Med Trop Sao Paulo 10: 265-276.

Souza-Lima, Barbosa MGV, Coura JR, Arcanjo ARL, Nascimento AS, Ferreira JMBB, Albuquerque BV, Araújo GAN, Guerra JAO 2013. Outbreak of acute Chagas disease in the Rio Negro region, Brazilian Amazon. Rev Soc Bras Med Trop 46: 510-514.

Valente SAS, Valente CV, Pinto AYN, César MJR, dos Santos MP, Miranda COS, Cuervo P, Fernandes O 2009. Analysis of an acute Chagas disease outbreak in the Brazilian Amazon: human cases, triatomines, reservoir mammals and parasites. Trans $R$ Soc Trop Med Hyg 103: 291-297.

Valente SAS, Valente VC, Fraiha Neto H 1999. Considerations on the epidemiology and transmission of Chagas disease in the Brazilian Amazon. Mem Inst Oswaldo Cruz 94 (Suppl. I): 395-398.

Valente VC 1999. Potential for domestication of Pantrongylus geniculatus (Latreille, 1811) (Liemiptera, Reduviidae, Triatominae) in the municipality of Muaná, Marajó Island, state of Pará. Mem Inst Oswaldo Cruz 94 (Suppl. I): 399-400.

Valente VC, Valente SAS, Noireau F, Carrasco HJ, Miles MA 1998. Chagas disease in the Amazon Basin: association of Pantrongylus geniculatus (Hemiptera: Reduviidae) with domestic pigs. $J$ Med Entomol 35: 99-103.

Wendel S, Dias JCP 1992. Transfusion-transmitted Chagas disease. In S Wendel, Z Brener, MG Camargo, A Rassi, Chagas disease (American trypanosomiasis): its impact on transfusion and clinical medicine, ISBT Brazil'92, São Paulo, p. 103-133.

Zeledón R, Marin F, Calvo N, Lugo E, Valle S 2006. Distribution and ecological aspects of Rhodnius pallescens in Costa Rica and Nicaragua and their epidemiological implications. Mem Inst Oswaldo Cruz 101: 75-79. 